\title{
Examining the measurement and dimensionality of the construct of consumer awareness in a developing and transition economy
}

\begin{tabular}{|c|c|}
\hline \multicolumn{2}{|c|}{$\begin{array}{l}\text { Authors: } \\
\text { Charles Makanyeza }^{1} \\
\text { Francois du Toit }{ }^{2}\end{array}$} \\
\hline $\begin{array}{l}\text { Affiliations: } \\
{ }^{1} \text { Marketing D } \\
\text { Chinhoyi Uni } \\
\text { Technology, Z }\end{array}$ & $\begin{array}{l}\text { epartment, } \\
\text { ersity of } \\
\text { imbabwe }\end{array}$ \\
\hline $\begin{array}{l}{ }^{2} \text { Graduate Sc } \\
\text { Leadership, } \\
\text { South Africa, }\end{array}$ & $\begin{array}{l}\text { ool of Business } \\
\text { niversity of } \\
\text { South Africa }\end{array}$ \\
\hline $\begin{array}{l}\text { Corresponde } \\
\text { Charles Maka }\end{array}$ & $\begin{array}{l}\text { nce to: } \\
\text { nyeza }\end{array}$ \\
\hline $\begin{array}{l}\text { Email: } \\
\text { cmakanyeza@ }\end{array}$ & yahoo.co.uk \\
\hline $\begin{array}{l}\text { Postal addres } \\
\text { Chinhoyi Uni } \\
\text { Technology, P } \\
\text { Chinhoyi, Zim }\end{array}$ & $\begin{array}{l}\text { s: } \\
\text { ersity of } \\
\text { rivate Bag } 7724 \text {, } \\
\text { babwe }\end{array}$ \\
\hline $\begin{array}{l}\text { Dates: } \\
\text { Received: } 23 \\
\text { Accepted: } 16 \\
\text { Published: } 19\end{array}$ & $\begin{array}{l}\text { Dct. } 2014 \\
\text { Mar. } 2015 \\
\text { June } 2015\end{array}$ \\
\hline $\begin{array}{l}\text { How to cite } t \\
\text { Makanyeza, } \\
\text { Toit, F. (2015) } \\
\text { the measurer } \\
\text { dimensionalit } \\
\text { construct of } \\
\text { awareness in } \\
\text { and transitior } \\
\text { SA Journal of } \\
\text { Psychology/S } \\
\text { Bedryfsielkun } \\
\text { \#1250, } 9 \text { page } \\
\text { org/10.4102/ }\end{array}$ & $\begin{array}{l}\text { is article: } \\
\text {., \& Du } \\
\text { Examining } \\
\text { nent and } \\
\text { y of the } \\
\text { onsumer } \\
\text { a developing } \\
\text { economy. } \\
\text { Industrial } \\
\text { A Tydskrif vir } \\
\text { de, 41(1), Art. } \\
\text { s. http://dx.doi. } \\
\text { sajip.v41i1.1250 }\end{array}$ \\
\hline $\begin{array}{l}\text { Copyright: } \\
\text { (C) 2015. The } \\
\text { Licensee: AOS } \\
\text { OpenJournals } \\
\text { licensed unde } \\
\text { Commons Att } \\
\text { License. }\end{array}$ & $\begin{array}{l}\text { Authors. } \\
\text { IS } \\
\text { This work is } \\
\text { r the Creative } \\
\text { ribution }\end{array}$ \\
\hline 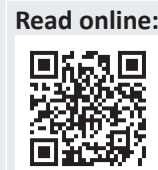 & $\begin{array}{l}\text { Scan this QR } \\
\text { code with your } \\
\text { smart phone or } \\
\text { mobile device } \\
\text { to read online. }\end{array}$ \\
\hline
\end{tabular}

Orientation: Literature suggests that major political and socio-economic transformations may influence the measurement and dimensionality of consumer awareness.

Research purpose: The study examined the measurement and dimensionality of the construct of consumer awareness after transformation in the political and socio-economic environments in Zimbabwe.

Motivation for the study: There is a dearth of research to validate whether or not the measurement and dimensionality of the construct of consumer awareness changes as the environment changes.

Research design, approach and method: Data were collected from a cross-section of 305 consumers using interviewer-administered questionnaires. Consumers were intercepted at shopping malls. Structural equation modelling was used to analyse data.

Main findings: The study confirmed that consumer awareness comprises five dimensions, namely product knowledge, bargain hunting, general consumer knowledge, price consciousness and information search. However, the study found that only 16 items, instead of the proposed 25, were relevant in measuring consumer awareness. Product knowledge, bargain hunting and information search were each measured by four items, whilst general consumer knowledge and price consciousness were each measured by two items. The other nine items were shown to be of no value.

Practical/managerial implications: The study recommends that marketers and policymakers in developing and transition economies, such as Zimbabwe, consider these five dimensions when conducting consumer awareness research or when planning consumer awareness programmes.

Contribution/value-add: The study provided evidence that the dimensionality of the construct of consumer awareness does not change as the socio-economic and political environments change. However, items used to measure the dimensions need to be updated from time to time.

\section{Introduction}

As the world increasingly becomes a global village, international trade has gained momentum. There has been a wide range of products crossing national boundaries (Ranjbarian, Rojuee \& Mirzaei, 2010; Teo, Mohamad \& Ramayah, 2011). This presents consumers not only with an increased product range from which to choose, but also with concerns about the quality of products that they consume. As such, product safety concerns continue to increase amongst consumers, leading to increased importance of the construct of consumer awareness in marketing research (Brewer \& Rojas, 2008; Rousseau \& Venter, 1995; Zakersalehi \& Zakersalehi, 2012).

Consumer awareness describes the extent to which consumers are aware of or alert to their rights and responsibilities in the marketplace (Rousseau \& Venter, 1995). The alertness of a consumer to their rights and responsibilities in the marketplace is critical in that it gives the consumer some sense of consciousness and direction when making purchase decisions. By being well-informed on product information as well as on consumer rights, the consumer is not only protected against exploitation but is also more likely to obtain maximum satisfaction of their household needs (Du Plessis, Rousseau \& Blem, 1994). Moreover, Du Plessis et al. (1994) submit that, as consumers become aware of their rights and responsibilities in the marketplace, they make informed purchase decisions, they can protect themselves and businesses are held accountable for their actions. This potentially leads to better-quality products, increased savings 
and improved quality of life within an economy (Du Plessis et al., 1994; Solomon, 2002).

Knowledge of consumer awareness is critical in the development of product policies. Policies that ensure that products are labelled correctly, that consumers can understand important information presented in advertising or that minority groups are not disadvantaged can be crafted based on the knowledge of consumer awareness. Likewise, as they understand consumers better, marketers are likely to meet the consumers' needs (Solomon, 2002). This may lead to customer satisfaction, which in turn, leads to customer loyalty and increased profits (Donoghue \& De Klerk, 2009). The ability of consumers to complain and seek redress - important for the effective functioning of the economy - is largely influenced by the extent to which consumers are aware of their rights and responsibilities in the marketplace (Ishak \& Zabil, 2012). The majority of consumers do not exercise their rights to protect themselves against unprincipled business practices due to ignorance (Du Plessis et al., 2007). Similarly, Donoghue and De Klerk (2009) observe that many consumers do not report their dissatisfaction to suppliers because of a lack of consumer awareness. This worsens the plight of consumers because suppliers are not aware of the customers' dissatisfaction. On the other hand, a lack of understanding of the drivers of dissatisfaction of consumers makes it difficult for suppliers to provide for the customer needs efficiently and effectively, as such consumer dissatisfaction goes unnoticed, the source of the dissatisfaction remains hidden and the dissatisfaction is also unresolved (Donoghue \& De Klerk, 2009). It is, therefore, imperative for marketers to grasp the level and measurement of consumer awareness in a particular marketplace.

Studies on the measurement of the construct of consumer awareness are scarce, specifically in emerging markets. The notable studies on the measurement of consumer awareness were conducted about two decades ago in South Africa (Rousseau \& Venter, 1996) and in Zimbabwe (Rousseau \& Venter, 1995). These studies both concluded that the construct of consumer awareness comprises five dimensions, namely bargain hunting, general consumer knowledge, product knowledge, information search and price consciousness. However, Donoghue and De Klerk (2009) and Rousseau and Venter (1996) observe that major political and economic transformations may influence the measurement of consumer awareness. In this regard, Pentz, Terblanche, and Boshoff (2013) suggest that researchers should be extremely cautious when using pre-existent scales in environments that are likely to change over time. Nevertheless, there is no empirical evidence to suggest whether or not the dimensionality of the construct of consumer awareness changes as the socioeconomic and political environments transform.

The current study, therefore, was conducted in Zimbabwe to explore and validate the dimensionality of the construct of consumer awareness through the processes of exploratory factor analysis (EFA) and confirmatory factor analysis (CFA). The findings of the study contribute to the current body of consumer awareness knowledge because literature does not provide evidence of a study that has validated the dimensionality of the consumer awareness scale after transformations in the socio-economic and political environments. Zimbabwe has experienced major political and socio-economic transformations since the last time consumer awareness was measured in the mid-1990s (Rousseau \& Venter, 1995). This provided a fertile ground to conduct the current research in order to determine whether the dimensionality of the construct of consumer awareness changes as the political and socio-economic environments transform.

\section{Literature review}

The focus of the literature review is on consumer awareness and consumerism in Zimbabwe.

\section{Consumer awareness}

As the pace of globalisation accelerates, there has been an increase in the movement of products across national boundaries (Ranjbarian et al., 2010; Teo et al., 2011). Whilst consumers have benefited from an increased range of products from which to choose, concerns have also been raised about the quality of products that they consume. This has led to an increased importance of research on consumer awareness (Brewer \& Rojas, 2008; Rousseau \& Venter, 1995; Zakersalehi \& Zakersalehi, 2012). Consumer awareness is described as 'the extent or alertness of individual consumers of their rights and responsibilities in the market place' (Rousseau \& Venter, 1995, p. 18). It manifests itself through five distinct factors, namely bargain hunting, general consumer knowledge, product knowledge, information search and price consciousness (Rousseau \& Venter, 1993, 1995, 1996). Bargain hunting describes the extent to which consumers obtain the same item for a lower price. Consumers with bargaining strength tend to obtain better deals from sellers than their counterparts. General consumer knowledge refers to the general knowledge acquired by consumers as they purchase products. This knowledge assists consumers in making informed purchase decisions. The extent to which consumers are aware of product attributes such as guarantees, expiry dates and checking media for new products and services is called product knowledge. Information search describes the extent to which consumers actively seek information in order to make informed purchase decisions. The extent to which consumers are aware of prices is referred to as price awareness. Consumers who are price conscious seek more accurate price information and are willing to process such information (Rousseau, 1991).

As a construct, consumer awareness is a subset of consumerism (Du Plessis et al., 1994). Similarly, Rousseau and Venter (1995) observe that the construct of consumer awareness evolved from literature on consumerism, consumer rights and consumer protection, which originated in the United States. Likewise, Du Plessis et al. (2007) note that consumer awareness is part of consumerism, which came to 
the fore as the discipline of consumer behaviour developed. Kotler, Keller, Brady, Goodman and Hansen (2009, p. 172) define consumerism as 'an organised movement of citizens and government designed to strengthen the rights and powers of buyers in relationship to sellers'. Du Plessis et al. suggest that consumerism deals with rights and privileges in the marketplace. They also argue that consumerism is directly and indirectly concerned with consumers as they make purchase decisions.

Ishak and Zabil (2012) observe that consumers play a significant role in any economy by complaining and seeking redress about their dissatisfactions. However, to do that, consumers need to be aware of their rights and responsibilities in the marketplace. The majority of consumers do not exercise their rights to protect themselves against undesirable business practices due to ignorance (Du Plessis et al., 2007). As such, Du Plessis et al. (2007) observe that many consumers do not report their dissatisfaction to manufactures and retailers. It is generally agreed, however, that the ability of consumers to seek redress is inherent in their level of understanding of their rights and responsibilities at the marketplace (Donoghue \& De Klerk, 2009). An alertness to their rights and responsibilities in the marketplace is especially important because it enables consumers to make informed decisions when making purchase decisions. Moreover, consumer awareness does not only protect consumers against exploitation but it is also more likely to lead to customer satisfaction (Du Plessis et al., 1994). Accordingly, customer satisfaction may lead to customer loyalty and increased profits (Donoghue \& De Klerk, 2009). As suggested by Solomon (2002), a sound understanding of consumer awareness is also important in the development of policies. Similarly, research plays a significant role in formulating or evaluating public policies that ensure increased consumer awareness and that products are labelled correctly (Solomon, 2002). Consumer awareness and knowledge also influence consumer purchase behaviour. As a result, consumer awareness and knowledge drive growth in product markets (Kumar \& Ali, 2011).

Consumer awareness is concerned with the alertness of consumers to their rights and responsibilities in the process of product exchange (Rousseau \& Venter, 1995). In this regard, the Consumer Council of Zimbabwe (CCZ, 2012) observes that consumers have rights, which must be protected. Likewise, consumers must exercise their rights by taking responsibility. Assael (2004), Du Plessis et al. (2007) and Kotler et al. (2009) agree that safeguarding the rights of consumers in the process of product exchange is the fundamental concern of consumerism in the protection of consumers.

Consumers International (2012) and Makela and Peters (2004) observe that consumerism has developed over the years based on the four fundamental consumer rights proposed by President Kennedy on 15 March 1962, namely the right to safety, the right to be informed, the right to choose and the right to be heard. Subsequently these basic rights have grown to eight by the addition of the right to satisfaction of basic needs (the right to basic needs), the right to redress, the right to consumer education and the right to a healthy environment (Consumers International, 2012). Accordingly, a set of eight basic consumer rights now define and inspire much of the work of Consumers International - the world's umbrella body for consumer organisations - and its members the world over (Consumers International, 2012). Du Plessis et al. (2007) suggest that there is the ninth right, namely the right to privacy.

Consumer responsibilities are concerned with the ability to form independent opinions with regard to an individual's own consumption behaviour, which can be argued for and acted upon (Rousseau \& Venter, 1995). Consumers International (2012) notes that consumer responsibilities were introduced after the then Consumers International president - Anwar Fazal - actively called for the introduction thereof in the 1980s. Consumer responsibilities were designed to complement the already existing consumer rights (CCZ, 2012; Consumers International, 2012). Likewise, Du Plessis et al. (1994) argue that, not only do consumers have rights, but they also have responsibilities in exercising these rights. They describe consumer responsibility as 'the acquisition of the necessary knowledge and skills to make independent and rational consumption choices in relation to society and the environment' (Du Plessis et al., 1994, p. 339). This implies acquiring knowledge and skills to make responsible choices that will benefit both the individual consumer and society ( $\mathrm{Du}$ Plessis et al., 1994). It also involves an awareness of perceived risks, such as financial risk, associated with purchase decisions. The CCZ (2012) and Makela and Peters (2004) identify the responsibilities of consumers as critical awareness, action, environmental awareness, social concern and solidarity.

\section{Consumerism in Zimbabwe}

The only organisation that deals with consumer issues in Zimbabwe is the CCZ, a quasi-government organisation whose principal objective is to be a watchdog for consumers (CCZ, 2012). A vigilance committee was formed by the then Rhodesian government in 1955 with the mandate of meeting protective needs of consumers and to produce better understanding between producers and consumers (CCZ, 2012). This vigilance committee was transformed in 1975 to form the present-day CCZ. The CCZ has been a registered member of Consumers International - the world's federation of consumer groups - since March 1981 (Consumers International, 2012). The mandate of the CCZ includes protection of consumers, protection of manufacturing standards, improvement of consumer awareness through education and settling of disputes between consumers and suppliers. The CCZ also recognises the rights of the consumers and ensures that these rights are respected (CCZ, 2012). These rights form the backbone of the work of the organisation. In this regard, the CCZ strives to educate consumers to understand their rights. The motive behind the education of consumers is to ensure that consumers are equipped for self-protection and that they can influence the 
government, policymakers or lawmakers to make policies and laws that take into account the interests of consumers (CCZ, 2012). The organisation also strives to monitor prices and standards of products for the benefit of the consumers. Lastly, the Council provides, inter alia, research services and general information (CCZ, 2012).

The CCZ has successfully conducted surveys on various goods and services, enabling the provision of researchbased information and also to unearth the malpractice of businesses in Zimbabwe (CCZ, 2012). Moreover, the CCZ has successfully monitored price trends and conducted monthly shopping-basket surveys, which are availed to its members (CCZ, 2012), although there are no research findings available in the public domain regarding the measurement of consumer awareness. The CCZ has also successfully lobbied for specific consumer legislation aimed at safeguarding the rights of consumers (CCZ, 2012). These acts include the Small Claims Court Act of 1992, Consumer Contracts Act of 1994, Patients Charter, Competition Act of 1996 and Class Action Act, Chapter 8:17. According to the CCZ (2012), the Small Claims Act ensures that low-income and middle-income earners who cannot afford legal representation have access to the courts whilst the Consumer Contracts Act seeks to protect consumers against unfair contracts. The Patients Charter creates an environment of mutual understanding, participation and humane treatment of patients (CCZ, 2012). Concerned with the encouragement and promotion of fair competition in all Zimbabwean sectors of the economy is the Competition Act (Chapter 14:28) of 1996. Finally, the Class Action Act (Chapter 8:17) of 1999 provides for consumers to seek legal redress jointly (CCZ, 2012).

\section{Objectives of the study}

The main objective of the study was to explore and validate the dimensionality of the construct of consumer awareness in Zimbabwe. The specific objectives of the study were: (1) to determine the dimensionality of the construct of consumer awareness in Zimbabwe and (2) to compare the present findings with those of Rousseau and Venter (1995).

\section{Research design Research approach}

A quantitative approach was adopted in this study. Bryman (2008) suggests that quantitative research enables the researcher to test theory. In this regard, the quantitative approach was found to be the most appropriate method since the study sought to validate the dimensionality of the construct of consumer awareness through a comparison of theory and research. A cross-sectional survey design was used to collect data from consumers in Harare and Bulawayo, the two major cities in Zimbabwe. A cross-sectional survey design involves measuring a phenomenon at a point in time; hence, it is just like a picture that tells the story as it takes place at a specific time (Bryman, 2008). In the present study, data were collected once (i.e. at a particular point in time). This was necessary because the study sought to use data only to determine the dimensions of consumer awareness and to compare with theory.

\section{Research method}

\section{Research participants}

According to Zimstat (2012), the total number of people who stay in Harare and Bulawayo is 1468767 and 655675 respectively. Data were collected from 400 consumers (i.e. 200 consumers each from Harare and Bulawayo) using a structured interviewer-administered questionnaire. The sample size of 400 was informed by prior related research (Bandara \& Miloslava, 2012; Jusoh \& Ling, 2012). Moreover, the sample size of 400 was justified following the recommendations by Field (2005) that a minimum sample size of 200 is required to permit such statistical analyses as factor extraction, as done in this study. Out of the 400 questionnaires, only 305 were completed and usable: 175 and 130 questionnaires from Harare and Bulawayo, respectively. The profile of the sample is summarised in Table 1.

Of the 305 respondents, $45.6 \%$ were male and $54.4 \%$ were female. Age was distributed as follows: $1.3 \%$ of the respondents were aged 18-19, 18.4\% were aged 20-24, 26.2\% were aged $25-29,30.5 \%$ were aged 30-39, 20.0\% were aged 40-49 and $3.6 \%$ were aged 50-59. In terms of the highest level of education attained, the distribution was as follows: $0.3 \%$ had attained Grade 7, 5.9\% had attained ZJC, $6.9 \%$ had attained O-Level, $10.8 \%$ had attained A-Level, 32.1\% had attained a diploma, 33.4\% had attained a bachelor's degree, 9.2\% had attained a master's degree and 1.3\% had attained a doctoral degree. In terms of monthly income, $42.0 \%$ were

TABLE 1: Sample profile.

\begin{tabular}{|c|c|}
\hline Description & $f(\%)$ \\
\hline \multicolumn{2}{|l|}{ Gender } \\
\hline Male & $139(45.6)$ \\
\hline Female & $166(54.4)$ \\
\hline \multicolumn{2}{|l|}{ Age } \\
\hline $18-19$ & $4(1.3)$ \\
\hline $20-24$ & $56(18.4)$ \\
\hline $25-29$ & $80(26.2)$ \\
\hline 30-39 & $93(30.5)$ \\
\hline $40-49$ & $61(20.0)$ \\
\hline $50-59$ & $11(3.6)$ \\
\hline \multicolumn{2}{|c|}{ Highest level of education } \\
\hline Grade 7 & $1(0.3)$ \\
\hline ZJC & $18(5.9)$ \\
\hline O-Level & $21(6.9)$ \\
\hline A-Level & $33(10.8)$ \\
\hline Diploma & $98(32.1)$ \\
\hline Bachelor's degree & $102(33.4)$ \\
\hline Master's degree & $28(9.2)$ \\
\hline Doctoral degree & $4(1.3)$ \\
\hline \multicolumn{2}{|c|}{ Monthly gross income (US\$) } \\
\hline Less than 500 & $128(42.0)$ \\
\hline 500-999 & $86(28.2)$ \\
\hline 1000-1499 & $55(18.0)$ \\
\hline 1500-1999 & $18(5.9)$ \\
\hline $2000+$ & 18 (5.9) \\
\hline
\end{tabular}

$f$, frequency. 
earning less than US\$500, 28.2\% were earning between US\$500 and US\$999, 8.0\% were earning between US\$1000 and US\$1499, 5.9\% were earning between US\$1500 and US\$1999, whilst 5.9\% were earning at least US\$2000.

\section{Measuring consumer awareness and designing the instrument}

Literature suggests that the most comprehensive scale to measure the construct of consumer awareness is the one developed and successfully applied by Rousseau and Venter (1992, 1993, 1995). Using this scale, Rousseau and Venter (1995) went on to measure consumer awareness in Zimbabwe. They concluded that the construct of consumer awareness consisted of five distinguishable characteristics (refer to Table 2).

As shown in Table 2, the consumer awareness scale comprised 25 items, meaning that each characteristic (dimension) of consumer awareness was measured using five items. The scale was based on a six-point Likert-type scale ranging from 1 ('agree completely') to 6 ('disagree completely') (Rousseau \& Venter, 1995) instead of the common seven-point Likert scale. The Cronbach's alpha $(\alpha)$ for the sub-scales were as follows: bargain hunting 0.69, general consumer knowledge 0.59, product knowledge 0.60 , information search 0.65 and price consciousness 0.73 (Rousseau \& Venter, 1995). According to Bryman (2008), these levels of reliability are acceptable.

Literature suggests that major political and economic transformations within a country are likely to influence how consumer awareness is measured (Donoghue \& De Klerk, 2009; Rousseau \& Venter, 1996). Researchers should therefore be extremely cautious when using scales developed in other environments that are likely to change over time (Pentz et al., 2013). To measure consumer awareness, the consumer awareness scale applied by Rousseau and Venter $(1995,1996)$ was used (see Table 2). Thus, the consumer awareness scale in the present study had 25 items which were coded as follows:

- Items AWNS1-5 measured bargain hunting.

- AWNS6-10 measured general consumer knowledge.

- AWNS11-15 measured product knowledge.

- AWNS16-20 measured information search.

- AWNS21-25 measured price consciousness.

Slight modifications to the original scale were made in order to make it applicable to the current environment in Zimbabwe:

- On the first item on the scale (AWNS1), the word 'newspaper' was replaced with 'media'.

- On the second item on the scale (AWNS2), the word 'radio' was replaced with the phrase 'the other media'.

- On the eighth item on the scale (AWNS8), the phrase 'online and electronic sources' was added at the end of the statement.

- On the 20th item on the scale (AWNS20), the phrase 'read newspaper advertisements' was replaced with 'consider advertisements'.

Respondents were asked to rate the statements based on a seven-point Likert-type scale ranging from 1 ('strongly

TABLE 2: Dimensionality of the consumer awareness scale.

\begin{tabular}{|c|c|c|}
\hline Dimension & Items & Reliability analysis (Cronbach's $\alpha$ ) \\
\hline \multirow[t]{5}{*}{ Bargain hunting } & I check the newspaper each week for bargains. & 0.69 \\
\hline & When I see a 'special' advertised on TV or radio I always follow it up. & - \\
\hline & I always shop at more than one store to compare prices and take advantage of the lowest priced item. & - \\
\hline & I like searching for bargains at seasonal sales auctions. & - \\
\hline & I always try to obtain the best deal. & - \\
\hline \multirow[t]{4}{*}{ General consumer knowledge } & $\begin{array}{l}\text { Consumers in Zimbabwe are not aware of their legitimate rights when it comes to doing business or } \\
\text { engage in shopping. }\end{array}$ & 0.59 \\
\hline & Too few consumers in Zimbabwe read consumer articles in newspapers and magazines. & - \\
\hline & Zimbabwe consumers are not aware of the laws available to protect their consumer rights. & - \\
\hline & Consumer organisations in Zimbabwe deserve better support from consumers. & - \\
\hline \multirow[t]{4}{*}{ Product knowledge } & Checking expiring dates on perishable food items is essential for ensuring fresh produce. & 0.60 \\
\hline & I always look for a guarantee on expensive products before deciding on the purchase. & - \\
\hline & It is important to share product information with friends and relatives. & - \\
\hline & Product knowledge is one's best guardian against exploitation. & - \\
\hline \multirow[t]{5}{*}{ Information search } & I always consult brochures and pamphlets for information before buying durable goods. & 0.65 \\
\hline & Seeking information from relatives prior to make a final choice is always a good idea. & - \\
\hline & Sales staff can be an important source of product information. & - \\
\hline & Before purchasing a particular product I usually compare various brands to choose the best. & - \\
\hline & I usually read newspaper advertisements for obtaining product information prior to purchase. & - \\
\hline \multirow[t]{5}{*}{ Price consciousness } & Choosing 'no-name brands' is a good way to beat inflation. & 0.73 \\
\hline & Price is the most important factor to me in choosing an item. & - \\
\hline & When a product is offered at a discount price I am more tempted to buy it. & - \\
\hline & Before deciding where to go shopping, I usually try to find out whether any specials are being offered. & - \\
\hline & I always compare prices of similar products on display in the store. & - \\
\hline
\end{tabular}

Source: Adapted from Rousseau, G.G., \& Venter, D.J.L. (1995). Measuring consumer awareness in Zimbabwe. Journal of Industrial Psychology, $21(1), 18-24$. 
disagree') to 7 ('strong agree'). Whilst Rousseau and Venter (1995) used a six-point Likert-type scale, the seven-point scale is used in the present study because it has the advantage of a midpoint value (4) which reflects indifference.

\section{Research procedure}

The respondents were intercepted at shopping malls and asked to respond to questions as they purchased products from major supermarkets whilst the researcher coded the responses. The general attitude of the respondents towards the study was positive; however, differences could be noticed in the two cities under investigation as indicated by the response rates (see the section on the research participants). In Harare, the respondents were more responsive in taking part in the study than in Bulawayo.

\section{Statistical analysis}

Data were cleaned, coded and entered into Statistical Package for the Social Sciences (SPSS), version 21. Exploratory factor analysis (EFA) was then performed in order to determine the factors underlying consumer awareness. This was followed by reliability analysis using Cronbach's alpha. Correlation analysis was also performed to determine whether or not the factors were related, checking for convergence validity. Finally, confirmatory factor analysis (CFA) was also executed in Analysis of Moment Structures (AMOS) version 21 to confirm the significance of the dimensions of the construct of consumer awareness.

\section{Results \\ Exploratory factor analysis}

EFA was performed in SPSS version 21 to determine the factors underlying the construct of consumer awareness. The initial step was to test for sampling adequacy and whether or not data permitted EFA to be performed. This was done using the Kaiser-Meyer-Olkin measure of sampling adequacy (KMO) and Bartlett's test of sphericity. The sample was found to be adequate $(\mathrm{KMO}$ statistic $=0.760)$. Data were found to permit EFA (chi-square $=1378.759$; degrees of freedom $=171$; $p<0.001)$. The decision to accept these measures was based on the recommendations by Bryman (2008), Field (2005) and Zikmund and Babin (2007) that KMO should be close to 1 and the Bartlett's test of sphericity should be significant with $p$ less than 0.5 . The results of EFA are summarised in Table 3.

Initially, six factors were extracted from the data. However, one of the factors not presented in Table 3 comprised a single item (AWNS25) with a negative loading. This factor was dropped because a single item is not likely to measure a concept reliably (Churchill, 1979; Eisinga, Te Grotenhuis \& Pelzer, 2013). One item (AWNS18) was dropped because of double loading, which caused confusion. Seven items (AWNS1, AWNS6, AWNS10, AWNS12, AWNS17, AWNS21 and AWNS22) were dropped because they displayed item-total correlations of less than 0.30. This follows the recommendations by Field (2005) that items displaying itemtotal correlations less than 0.30 should be dropped because they do not measure a concept reliably. From the original and proposed 25 items, only 16 items remained after conducting the EFA as shown in Table 3.

As shown in Table 3, the first factor comprised four items whose focus was knowledge about products; hence, the factor was referred to as product knowledge. The second factor comprised four items whose focus was explaining consumer bargaining. Therefore, this factor was referred to as bargain hunting. The third factor was made up of two items that explained the general knowledge of consumers, hence the name general consumer knowledge. The fourth factor consisted

TABLE 3: Results of exploratory factor analysis.

\begin{tabular}{|c|c|c|c|c|c|c|}
\hline Factor & Items & Mean & Standard deviation & Factor loadings & $\begin{array}{l}\text { Item-total } \\
\text { correlations }\end{array}$ & $\begin{array}{c}\text { Reliability analysis } \\
\text { (Cronbach's } \alpha)\end{array}$ \\
\hline \multirow[t]{4}{*}{ Product knowledge } & AWNS11 & 6.44 & 1.172 & 0.752 & 0.622 & 0.778 \\
\hline & AWNS13 & 5.89 & 1.347 & 0.741 & 0.602 & - \\
\hline & AWNS14 & 6.07 & 1.199 & 0.687 & 0.594 & - \\
\hline & AWNS7 & 5.84 & 1.426 & 0.601 & 0.498 & \\
\hline \multirow[t]{4}{*}{ Bargain hunting } & AWNS5 & 5.75 & 1.523 & 0.685 & 0.417 & 0.629 \\
\hline & AWNS2 & 3.95 & 1.791 & 0.668 & 0.366 & - \\
\hline & AWNS3 & 5.59 & 1.747 & 0.590 & 0.463 & - \\
\hline & AWNS4 & 4.14 & 2.045 & 0.566 & 0.378 & - \\
\hline \multirow[t]{2}{*}{ General consumer knowledge } & AWNS8 & 5.22 & 1.693 & 0.824 & 0.520 & 0.684 \\
\hline & AWNS9 & 5.29 & 1.735 & 0.815 & 0.520 & - \\
\hline \multirow[t]{2}{*}{ Price consciousness } & AWNS23 & 4.86 & 1.752 & 0.688 & 0.427 & 0.598 \\
\hline & AWNS24 & 4.41 & 1.837 & 0.538 & 0.427 & - \\
\hline \multirow[t]{4}{*}{ Information search } & AWNS15 & 5.09 & 1.581 & 0.749 & 0.415 & 0.580 \\
\hline & AWNS16 & 5.04 & 1.702 & 0.732 & 0.413 & - \\
\hline & AWNS20 & 4.46 & 1.676 & 0.481 & 0.318 & - \\
\hline & AWNS19 & 5.97 & 1.197 & 0.463 & 0.311 & - \\
\hline
\end{tabular}

Extraction method: Principal component analysis.

Rotation method: Oblimin with Kaiser normalisation.

Rotation converged in 19 iterations.

Based on eigenvalues $>1.00$

Total variance explained $=59.654 \%$.

Loadings of less than 0.4 were suppressed. 
of two items that focused on the level of price consciousness amongst consumers. Therefore, the factor was named price consciousness. The fifth factor consisted of four items whose main focus was how consumers search for information in order to make purchase decisions. As such, the factor was named information search.

The next step was to determine the reliability of the subscales that measured the extracted factors. This was done using Cronbach's alpha as shown in Table 3. Sub-scales to measure product knowledge, bargain hunting and general consumer knowledge revealed acceptable reliabilities. Subscales to measure price consciousness and information search displayed fairly acceptable reliabilities. Zikmund, Babin, Carr, and Griffin (2010), Bryman (2008) and Field (2005) suggest that sub-scales displaying such reliabilities may be worked with.

\section{Confirmatory factor analysis}

CFA was performed in AMOS version 21 to validate the fivedimensionality of the construct of consumer awareness (see model fit indices in Table 4 and the measurement model in Figure 1).

As illustrated in Table 4, the measurement model for the five-dimensional consumer awareness scale revealed acceptable fit indices. Hooper, Coughlan and Mullen (2008) and Reisinger and Mavondo (2007) suggest that the value of chi-square and degree of freedom should be less than three or should be in the ratio of 3:1. The goodness of fit index, adjusted goodness of fit index and Bentler comparative fit index should be close to 1 (Hooper et al., 2008; Reisinger \& Mavondo, 2007; Schreiber, Nora, Stage, Barlow \& King, 2006). Hooper et al. (2008) suggest that a value of the root mean square error of approximation of between 0.05 and 0.1 is acceptable.

The next step was to assess the measurement model estimates. The estimates show that the model fit is significant. All factor loadings (standardised regression weights in the measurement model) were higher than 0.4 (Field, 2005) and significant with $p$ less than 0.001 (see Figure 1). The critical ratios (CRs) ranged between 4.844 and 9.299, suggesting that they were significantly higher than 0 in each path. Correlations between latent variables were significant as illustrated in Table 5.

TABLE 4: Model fit indices.

\begin{tabular}{lc}
\hline Measurement & Index \\
\hline Sample size & 305 \\
Chi-square $\left(\chi^{2}\right)$ & 253.612 \\
Degrees of freedom $(d f)$ & 94 \\
$\chi^{2} / d f$ & 2.698 \\
Goodness of fit index $(\mathrm{GFI})$ & 0.901 \\
Adjusted GFI (AGFI) & 0.900 \\
Bentler comparative fit index (CFI) & 0.916 \\
Root mean square error of approximation (RMSEA) & 0.070 \\
\hline
\end{tabular}

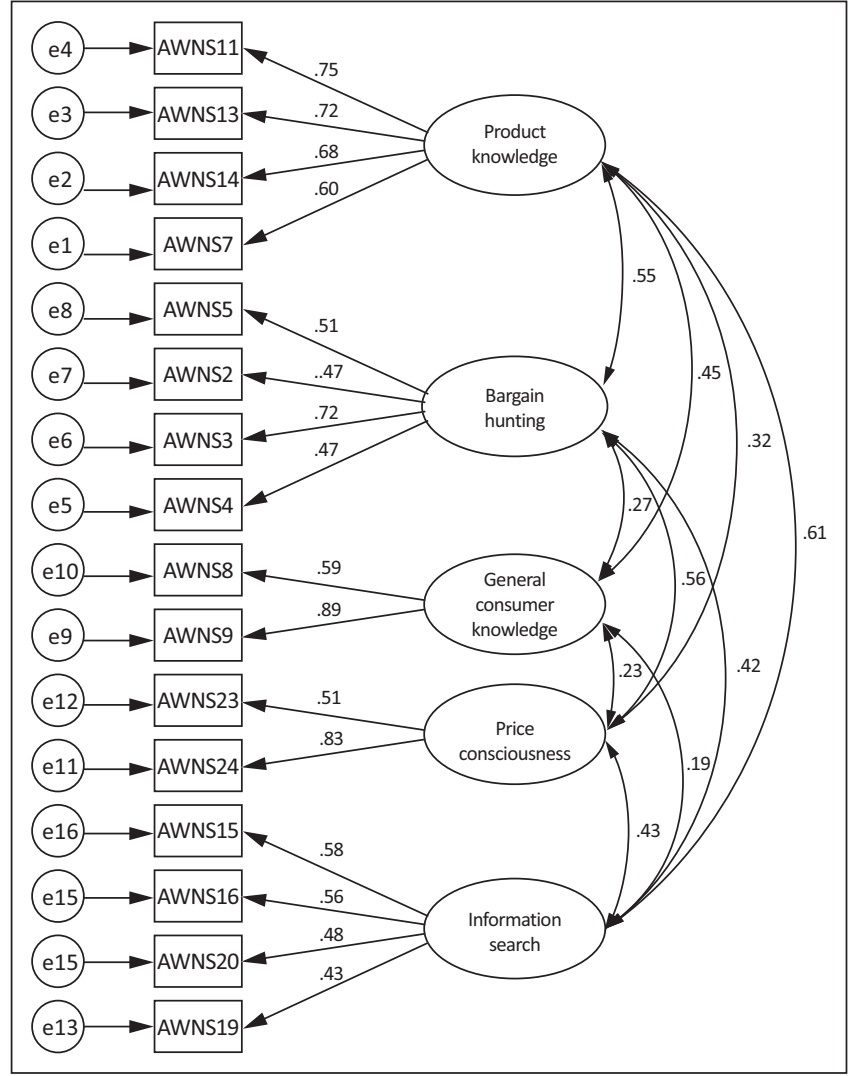

FIGURE 1: The measurement model.

The CRs ranged between 2.178 and 5.226, an indication that that they were sufficiently large. Although they correlated significantly, the dimensions of consumer awareness did not highly correlate (correlations ranged between 0.212 and 0.611). This implies that, although these dimensions are related, they can still be regarded as different in Zimbabwe.

\section{Discussion and implications}

The study sought to examine the measurement and dimensionality of the construct of consumer awareness in Zimbabwe, a developing and transition economy. The choice of Zimbabwe was motivated by the fact that the country has experienced major political and socio-economic transformations since consumer awareness was last measured in the mid-1990s. As documented in literature, major transformations in the political and socio-economic environments may influence the measurement of consumer awareness.

In support of the seminal work on the dimensions of the construct of consumer awareness by G.G. Rousseau and Venter $(1995,1993)$ and D. Rousseau and Venter (1992), the findings suggested that the construct of consumer awareness comprises five related but different factors, namely bargain hunting, general consumer knowledge, product knowledge, information search and price consciousness. As such, these five dimensions may be applied when measuring consumer awareness in developing and transition countries such as Zimbabwe. However, the present study proposes that these 
TABLE 5: Correlations between dimensions of consumer awareness.

\begin{tabular}{|c|c|c|c|c|c|}
\hline Correlations between factors & & & Estimate & CR & $P$ \\
\hline Product knowledge & $\leftrightarrow$ & Information search & 0.611 & 4.502 & $* * *$ \\
\hline Product knowledge & $\leftrightarrow$ & Price consciousness & 0.322 & 3.897 & $* * *$ \\
\hline Product knowledge & $\leftrightarrow$ & General consumer knowledge & 0.446 & 5.226 & $* * *$ \\
\hline Product knowledge & $\leftrightarrow$ & Bargain hunting & 0.549 & 4.632 & $* * *$ \\
\hline Bargain hunting & $\leftrightarrow$ & Information search & 0.416 & 3.374 & $* * *$ \\
\hline Bargain hunting & $\leftrightarrow$ & Price consciousness & 0.564 & 4.923 & $* * *$ \\
\hline Bargain hunting & $\leftrightarrow$ & General consumer knowledge & 0.275 & 3.143 & 0.002 \\
\hline General consumer knowledge & $\leftrightarrow$ & Information search & 0.212 & 2.178 & 0.029 \\
\hline General consumer knowledge & $\leftrightarrow$ & Price consciousness & 0.234 & 3.055 & 0.002 \\
\hline Price consciousness & $\leftrightarrow$ & Information search & 0.427 & 3.883 & $* * *$ \\
\hline
\end{tabular}

***, $p$ denotes probability less than 0.001 .

five dimensions should be measured by applying 16 items instead of 25 items in the previous studies: bargain hunting, product knowledge and information search are each measured by four items whilst general consumer knowledge and price consciousness are each measured by two items. This achieves relatively the same reliability of the sub-scales (refer to Table 2 and Table 3).

These findings imply that the general factor structure of the construct of consumer awareness did not change due to changes in the political and socio-economic environments. However, the items that measure the factors underlying this construct are subject to variation as the environment changes. The plausible explanation is that items on the scale are likely to be influenced by environmental conditions, rendering them inapplicable in the present environment. For example, major transformations in technology have affected the socio-economic environment - the way people do business has changed significantly over the past few decades due to technology (Cateora, Gilly \& Graham, 2009). Social media marketing has taken centre stage and the technology-literate consumers are now acquiring a much of their product information via this platform. This seems to affect the items that can possibly be applied when measuring consumer awareness. As such, there is a need to adapt the items to suit the present environmental conditions. This supports the view held by Donoghue and De Klerk (2009) and Rousseau and Venter (1996) that major political and economic transformations within a country are likely to influence how consumer awareness is measured. Similarly, Pentz et al. (2013) suggest that caution should be taken when using scales developed in other environments that are likely to change over time.

The study recommends that marketers and policymakers in developing and transition economies such as Zimbabwe consider the five dimensions of the construct of consumer awareness, namely product knowledge, bargain hunting, general consumer knowledge, price consciousness and information search when conducting consumer awareness research or when planning consumer awareness programmes. Marketers are advised to provide adequate information concerning products. This can be done by including the necessary information on packaging. Informative advertisements can also be shown on television or can be aired on radio. Print media such as newspapers can also be used to provide information to consumers. Providing product information to consumers is likely to make it easier for consumers to make informed purchase decisions. The relatively high levels of education urge marketers to explore technology-driven information campaigns such as social media. Media, especially electronic media, has obviously also globalised. The study is also useful in directing marketers' efforts towards the 16 items that have been shown to be currently relevant and avoiding waste on the other nine, which are not applicable any more. On the other hand, policymakers should come up with awareness programmes that focus on educating consumers in terms of general consumer knowledge, how to search for product information and how to maximise their utility when purchasing products. Moreover, marketers in developing and transition economies should pay particular attention to price, as this appears to be an important factor determining consumer awareness.

The study has limitations that provide a point of departure for future research. The sample was limited to Harare and Bulawayo, the two major cities in Zimbabwe; yet Zimbabwe has several other cities. Moreover, the greater proportion of the population of Zimbabwe is based in rural areas. It is therefore recommended that future studies consider other cities as well as rural areas in order to have a more representative sample. Besides, it is recommended that future research replicate the present study in other developing and transition economies to validate the measurement and dimensionality of the construct of consumer awareness.

\section{Acknowledgements Competing interests}

The authors declare that they have no financial or personal relationships that may have inappropriately influenced them in writing this article.

\section{Authors' contributions}

C.M. (Chinhoyi University of Technology) oversaw the collection and analysis of the data and contributed to the choice of methodology, the interpretation of the results, the conclusions drawn from it and the writing of the manuscript. F.T. (University of South Africa) contributed to 
the choice of methodology, the interpretation of the results, the conclusions drawn from it and the writing of the manuscript.

\section{References}

Assael, H. (2004). Consumer behaviour: A strategic approach. Boston, MA: Houghton Mifflin Company.

Bandara, W.W.M.C., \& Miloslava, C. (2012). Consumer ethnocentrism and attitudes towards foreign beer brands: With evidence from Zlin Region in the Czech Republic. Journal of Competitiveness, 4(2), 3-19. http://dx.doi.org/10.7441/ joc.2012.02.01

Brewer, M.S., \& Rojas, M. (2008). Consumer attitudes toward issues in food safety. Journal of Food Safety, 28(1), 1-22. http://dx.doi.org/10.1111/j.17454565.2007.00091.x

Bryman, A. (2008). Social research methods. (3rd edn.). New York, NY: Oxford University Press.

Cateora, P.R., Gilly, M.C., \& Graham, J.L. (2009). International marketing. (14th edn). New York, NY: McGraw-Hill/Irwin. http://dx.doi.org/10.1557/PROC-11231123-P03-08

Churchill, G.A. Jr. (1979). A paradigm for developing better measures of marketing constructs. Journal of Marketing Research (pre-1986), XVI, 64-73. http://dx.doi. org/10.2307/3150876

Consumer Council of Zimbabwe (CCZ). (2012). Consumer rights and responsibilities. Retrieved July 17, 2012, from http://www.ccz.org.zw/rights/index.php

Consumers International. (2012). President Kennedy's declaration of consumer rights. Retrieved July 17, 2014, from http://www.consumersinternational.org/who-weare/consumer-rights

Donoghue, S., \& De Klerk, H.M. (2009). The right to be heard and to be understood: A conceptual framework for consumer protection in emerging economies. International Journal of Consumer Studies, 33(1), 456-467. http://dx.doi. org/10.1111/j.1470-6431.2009.00773.x

Du Plessis, P.J., Rousseau, G.G., \& Blem, N.H. (1994). Consumer behaviour: Strategic marketing applications. (2nd edn.). Halfway House, South Africa: Southern Book.

Du Plessis, P.J., Rousseau, G.G., Boshoff, C., Ehlers, L., Engelbrecht, M., Joubert, R. et al. (2007). Buyer behaviour: Understanding consumer psychology and marketing (4th edn.). Cape Town: Oxford University Press Southern Africa.

Eisinga, R., Te Grotenhuis, M., \& Pelzer, B. (2013). The reliability of a two-item scale: Pearson, Cronbach, or Spearman-Brown? International Journal of Public Health 58(1), 637-642. http://dx.doi.org/10.1007/s00038-012-0416-3

Field, A. (2005). Discovering statistics using SPSS. (2nd edn.). London: Sage.

Hooper, D., Coughlan, J., \& Mullen, M. (2008). Structural equation modelling Guidelines for determining model fit. Electronic Journal of Business Research Methods, 6(1), 53-60.

Ishak, S., \& Zabil, N.F.M. (2012). Impact of consumer awareness and knowledge on consumer effective behaviour. Asian Social Science, 8(13), 108-114. http://dx.doi. org/10.5539/ass.v8n13p108

Jusoh, Z.M, \& Ling, G.H. (2012). Factors influencing consumers' attitudes toward e-commerce purchases through online shopping. International Journal of Humanities and Social Science, 2(4), 223-230.
Kotler, P., Keller, K.L., Brady, M., Goodman, M., \& Hansen, T. (2009). Marketing management. Essex: Pearson Education.

Kumar, S., \& Ali, J. (2011). Analysing the factors affecting consumer awareness on organic foods in India. Paper presented at the 21st Annual IFAMA World Forum and Symposium on the Road to 2050: Sustainability as a Business Opportunity, Frankfurt, Germany, 20-23 June 2011.

Makela, C.J., \& Peters, S. (2004). Consumer education: Creating consumer awareness among adolescents in Botswana. International Journal of Consumer Studies, 28(4), 379-387. http://dx.doi.org/10.1111/j.1470-6431.2004.00402.x

Pentz, C., Terblanche, N.S., \& Boshoff, C. (2013). Measuring consumer ethnocentrism in a developing context: An assessment of the reliability, validity and dimensionality of the CETSCALE. Journal of Transnational Management, 18(13), 204-218. http:// dx.doi.org/10.1080/15475778.2013.817260

Ranjbarian, B., Rojuee, M., \& Mirzaei, A. (2010). Consumer ethnocentrism and buying intentions: An empirical analysis of Iranian consumers. European Journal of Social Sciences, 13(3), 371-386.

Reisinger, Y., \& Mavondo, F. (2007). Structural equation modelling. Journal of Travel \& Tourism Marketing, 21(4), 41-71. http://dx.doi.org/10.1300/J073v21n04_05

Rousseau, D. (1991). Identifying criteria of consumer awareness: A pilot study. Journal of Industrial Psychology, 17(3), 4-12.

Rousseau, D., \& Venter, D.J.H. (1992). Measuring identified criteria of consumer awareness for various demographic categories among two independent samples. Journal of Industrial Psychology, 18(3), 18-24. http://dx.doi.org/10.4102/sajip. v17i3.528

Rousseau, G.G., \& Venter, D.J.L. (1993). Measuring consumer awareness in a developing country. Journal of Industrial Psychology, 19(3), 6-12. http://dx.doi. org/10.4102/sajip.v19i3.560

Rousseau, G.G., \& Venter, D.J.L. (1995). Measuring consumer awareness in Zimbabwe. Journal of Industrial Psychology, 21(1), 18-24. http://dx.doi.org/10.4102/sajip. v21i1.584

Rousseau, G.G., \& Venter, D.J.L. (1996). A comparative analysis of consumer awareness in South Africa during 1992 and 1994: Implications for the reconstruction and development programme (RDP). Journal of Industrial Psychology, 22(2), 26-31. $\mathrm{http} / / / \mathrm{dx}$.doi.org/10.4102/sajip.v22i2.607

Schreiber, J.B., Nora, A., Stage, F.K., Barlow, E.A., \& King, J. (2006). Reporting structural equation modeling and confirmatory factor analysis results: A review. The Journal of Educational Research, 99(6), 323-338. http://dx.doi.org/10.3200/ JOER.99.6.323-338

Solomon, M.R. (2002). Consumer behaviour. Upper Saddle River, NJ: Prentice Hall.

Teo, P.C., Mohamad, O., \& Ramayah, T. (2011). Testing the dimensionality of consumer ethnocentrism scale (CETSCALE) among a young Malaysian consumer market segment. African Journal of Business Management, 5(7), 2205-2816.

Zakersalehi, M., \& Zakersalehi, A. (2012). Consumers' attitude and purchasing intention toward green packaged foods: A Malaysian perspective. Paper presented at the 2012 International Conference on Economics, Business Marketing and Management, Singapore, 26 February 2012.

Zikmund, W.G., \& Babin, B.J. (2007). Marketing research. New Delhi: Cengage Learning. Zikmund, W.G., Babin, B.J., Carr, J.C., \& Griffin, M. (2010). Business research methods. (8th edn.). Mason, OH: South-Western, Cengage Learning.

Zimstat. (2012). Census 2012 preliminary report. Retrieved January 13, 2013, from http://www.zimstat.co.zw 